\title{
Grain Crisis at Prusa
}

\section{Persuading the People in the Imperial Period}

\author{
Thierry V. Oppeneer
}

Ghent University, Dept. of History

Thierry.Oppeneer@UGent.be

\begin{abstract}
This contribution examines an assembly speech that was pronounced by Dio of Prusa in the context of a grain crisis $(\mathrm{Or} .46)$ in order to provide new insights into the politics of the Greek polis under Rome. Whereas inscriptions highlight the eagerness and zeal displayed by elite citizens in helping out their fatherlands, this speech points to the existence of tensions and conflict in the resolution of food crises. The oration's rhetorical strategies oscillate between the expectations of a popular audience and an elite politician's desire to shape and control those expectations. A rhetorical analysis of these strategies indicates that Prusan politics was grounded in a civic discourse that provided the people with the ideological means to assert real influence in the local political process. The $46^{\text {th }}$ oration thus attests to the persistence of a democratic tradition of popular political participation in a time when elites had become increasingly powerful.
\end{abstract}

\section{Keywords}

Dio of Prusa - imperial Greek city - assembly - rhetoric - deliberative oratory

At some point in the 70s AD, Dio of Prusa, the orator who became known to later generations as 'the golden mouthed,' took the floor during a turbulent assembly meeting in his native city. ${ }^{1}$ The $46^{\text {th }}$ oration of the Dionic corpus purports to be the speech delivered on this occasion. ${ }^{2}$ The surviving speech indicates that the assembly was summoned in response to popular unrest prompted by a local grain shortage (\$8) and a concomitant rise in the prices of grain $(\$ 10) .{ }^{3}$ From the speech, it appears rumours were going around that Dio was either unwilling to supply money for the purchase of grain or even deliberately withholding grain from the market in order to drive up its price. Prior to the assemblymeeting, these suspicions had incited a crowd armed with torches and stones to march on the estates of Dio and an unnamed other man ( $\S 6,11-12)$. For reasons that are unclear a confrontation between the

\footnotetext{
${ }^{1}$ For the date of the speech, see von Arnim 1899, 374-376; Jones 1978, 134; Bekker-Nielsen 2008, 177.

${ }^{2}$ It is impossible to determine if the textus receptus closely corresponds to a speech that was actually performed in reality. Brunt 1994, 35 n. 42, argues that the Bithynian orations are too vague to be close to real assembly speeches and must have been published for readers who had no interest in Prusan politics. Kemezis 2019, 84, 86, similarly points to their oddly generic nature to argue that they were, in part, written with an eye to a wider, external audience in addition to the internal addressees of the speeches. It is also possible, I would add, that the vagueness of the orations is a consequence of the fact that the audience was well aware of the circumstances and that elaborating on them would be unnecessary and, as Aristotle already remarked, rhetorically unwise ( $R h$. 3.14.11, 1415b32-1416a1; 3.16.11, 1417b11-16).

${ }^{3}$ Most scholars take the assembly to be the place of delivery, see e.g. Jones 1978, 20; Salmeri 2000, 64. Vujčić 2009,165 , on the other hand, argues that there is no internal evidence to support this assumption. Yet, it would

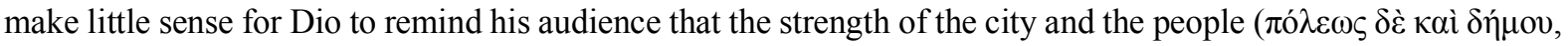
2) comes from wisdom and fair dealing, if he would not be addressing what he perceived to be a legitimate session of the ekklessia. In addition, the proposal made at the end of the speech was to be voted on by the present audience ( $\beta o v ́ \lambda \eta \sigma \theta \varepsilon \ldots$ v $\mu \tilde{i} v, 14$ ) and not by a later, official meeting of either the council or assembly.
} 
orator and the riotous crowd never ensued. Instead, a special session of the assembly was convened giving Dio the opportunity to perform an apologia in which he vigorously denies any involvement in the crisis and denounces the behaviour of the mob.

It is difficult to determine whether Dio had really only just escaped with his life, since our only source of information is the orator himself. What we do know, is that civic unrest on account of local food shortages was a recurring problem for the ancient city. ${ }^{4}$ It has been argued that popular hostility against Dio was instigated by his political rivals who turned the exasperation of the crowd to their own advantage. ${ }^{5}$ Yet, we do not need to presuppose the existence of elite manipulators or a starving mob to explain the hostility directed towards Dio. Taking their cue from studies on early modern Europe, several ancient historians have stressed the importance of the so-called moral economy, widely shared beliefs about the proper role of elites in times of scarcity. ${ }^{6}$ Local elites were expected to regulate the market and intervene if necessary in order to safeguard a steady food supply and just prices. Popular violence, they argue, was not so much caused by starvation as by perceived violations of the moral economy. ${ }^{7}$ With this in mind, it is not difficult to imagine how rumours about grain hoarding could have infused a mob to march on Dio's estate. It is clear that these rumours could not go unanswered and that measures had to be taken to resolve the crisis. At the end of his speech, Dio therefore proposes that the assembly elect market supervisors from among the men who had sufficient means but had not

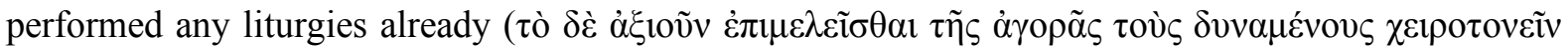

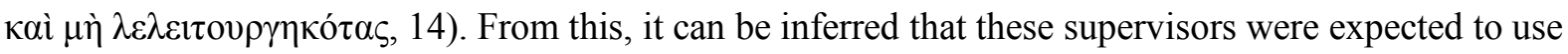
their own wealth to finance a market intervention.

The proposal Dio presents to the people of Prusa is in line with the measures for the resolution of food crises we commonly find in the many honorary inscriptions generated by the Greek cities in the first centuries AD. Interventions in the grain supply were financed either through public money from

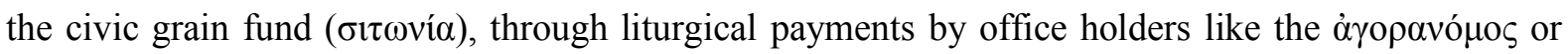
$\sigma \iota \tau \dot{v} \eta \varsigma$, or through benefactions of private individuals. ${ }^{8}$ Although there are no indications that a grain fund existed in Prusa, there are several second-century attestations of generous agoranomoi. An honorific inscription erected by one of the phylai, for example, commends a certain Publius Aelius

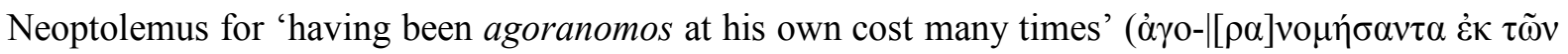

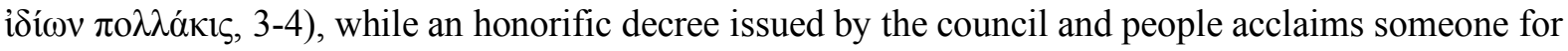
having fulfilled this office in an 'honour-loving way' ( $\varphi \imath \lambda$ í $\mu \omega \varsigma, 8){ }^{9}$ It is unlikely that the overseer of the market we encounter in Dio's proposal can be equated with the agoranomos. Since inscriptions tend to highlight instances of generosity that went above and beyond the normal liturgical obligations of the office, the function of overseer of the market should probably be seen as a compulsory liturgy created

\footnotetext{
${ }^{4}$ On the recurrence of food shortages, see Garnsey 1988, 8-16; Alston and van Nijf 2008. For attestations of civic unrest, see Philostr. VS 526, VA 1.15; Amm. Marc. 14.7.5-6; Tac. Ann. 6.13.1; Suet. Cl. 18.2.

${ }^{5}$ Fernoux 2011, 112-114. The suggestion that some notables had bribed people to join the attack against Dio seems unwarranted.

${ }^{6}$ On the moral economy in early modern Europe, see Thompson 1971; Tilly 1971.

${ }^{7}$ Erdkamp 2002; Broekaert and Zuiderhoek 2012, 77-80; Zuiderhoek 2013, 301-304.

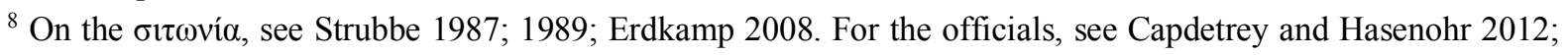
Migeotte 2015. On food-related benefactions, see Zuiderhoek 2013.

${ }^{9}$ I.Prusa ad Olymp. 21 (after Antoninus Pius); I.Prusa ad Olymp. 16 (Hadrianic period or slightly later). My translation having consulted Corsten 1991, 31-33, 37-39.
} 
in an emergency rather than a recurring office like that of the agoranomos.${ }^{10}$ It is clear, nevertheless, that one or more of Prusa's notables were expected to resolve the crises by supplying money 'out of

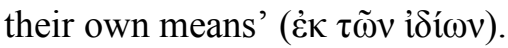

The $46^{\text {th }}$ oration is an intriguing text. In contrast with the honour-loving officials of the inscriptions cited above, Dio is not at all eager to take on the responsibility of market supervisor. As we will see later on in more detail, he deliberately tries to exclude himself from the pool of liturgical candidates by arguing that he had already performed many liturgies (§6). The standoff between Dio and the people of Prusa presents a sharp contrast to the image of eager benefactors, generous magistrates and grateful populaces that is displayed in the epigraphic record. This image was, of course, carefully constructed to serve the interests of both the honorands and the honorific community: for elite citizens, inscriptions presented a means of self-promotion, while the community sought to solicit further benefactions by displaying its willingness to recompense benefactors with the appropriate honours. Whereas inscriptions tend to give us little information about the political process whose outcome they document, Dio's oration presents us with a unique opportunity to get a glimpse of the ideological programme behind honorific epigraphy and the political manoeuvring that sometimes accompanied the resolution of food crises. ${ }^{11}$

This article does not aim to pin down the historical content of the oration. Instead, it concentrates on the text's rhetorical strategies in order to bring out its persuasive force. The rhetorical analysis presented here aims to provide new insights into the political processes at work in the imperial assembly. Even though Dio's orations are sometimes cited as evidence for the vitality of the assembly, so far no attention has been paid to what the orator's rhetorical strategies can tell us about the political culture of the imperial Greek city. ${ }^{12}$ It was a basic principle of ancient rhetorical theories that the effectiveness of a speaker's argumentation depended, in part, on its congruity with the expectations and beliefs of the audience. ${ }^{13}$ Since Dio was a well-trained orator, we can presume that his argumentative strategies were designed to fit the ideological framework of his audience. This does not mean that the oration simply reflects or reproduces the views of the people. Like all politicians, Dio sought to take an active role in shaping and reconfiguring the beliefs of his audience. His arguments had to start, however, from commonly held opinions. ${ }^{14}$ This article therefore concentrates on the rhetorical strategies of the $46^{\text {th }}$

\footnotetext{
${ }^{10}$ See Jones 1978, 19-20; contra Corsten 1993, 60 n. 71. It is possible, moreover, that Dio was agoranomos at the time of the crisis together with the unnamed other individual. This would explain why they were singled out from among the rest of the Prusan landowning elite.

${ }^{11}$ Some of the larger epigraphic dossiers also allow us a view into the politics behind their establishment (e.g. I.Ephesos 1419, 1492, 1493; TAM III.1. I.Chios 222). For a discussion, see Oppeneer 2018, 226-227, with further references.

${ }^{12}$ With political culture, I refer to the shared assumptions, ideas and beliefs that are commonly accepted as legitimate grounds for political claims and actions by members of a political community. For the concept of political culture in relation to the post-Classical polis, see van Nijf and Alston 2011, 11; Gray 2015, 6-14. On the Bithynian orations (Orr. 38-51) as evidence for the vitality of the assembly, see Zuiderhoek 2008, 418-423; Heller 2009, 347-349; Vujčić 2009; van Nijf 2013, 355-356.

${ }^{13}$ See e.g. Arist. Rh. 1.1.11-12, 1355a3-29; 1.9.30, 1367b7-11; 2.21.15, 1395a32-1395b11; 3.14.11, 1415b26-32; Cic. Orat. 24; Theon Prog. 115.24 Sp. II; Nicol. Prog. 64.5 Felten.

${ }^{14}$ It is interesting to note in this respect that Plutarch of Chaeronea, Dio's near-contemporary, urges aspiring politicians to get to know the character of the people and accommodate themselves to it, especially in the early stages of their careers (Praec. ger. reip. 799b-800c).
} 
oration as a way into the ideas and beliefs that were regarded as legitimate grounds for political claims and action in imperial Prusa. ${ }^{15}$

In this way, I aim to contribute to the new, emerging orthodoxy that challenges the traditional view of the imperial poleis as strongly oligarchic societies dominated by a few wealthy families who monopolised public offices and controlled the political decision-making process via the council. ${ }^{16}$ Over the past decade, this view has been challenged by several studies that point to the vitality and ongoing importance of the assembly in the political life of the imperial Greek city. ${ }^{17}$ The reality and extent of popular political participation via the assembly remain, however, the subject of debate and scholarly scepticism. ${ }^{18}$ This article, on the other hand, argues for the persistence of a democratic tradition of 'people politics,' a process of negotiation that took place in the assembly and was grounded in a civic discourse that provided the demos with the ideological means to assert real influence in local politics.

\section{Preparing the Stage}

In the prooimion of the speech, Dio argues from the topics of justice and injustice in order to convince

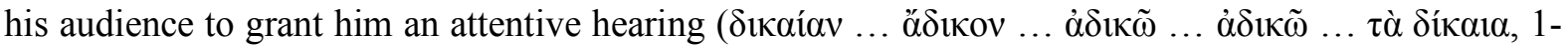
2). ${ }^{19}$ To this end, he employs several rhetorical devices and strategies that are meant to create an

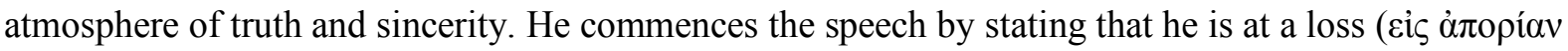
örov, 1), since he cannot see the cause for the people's anger towards him. This is followed by a rhetorical question - 'Who could heal anger that is unjust?' - that contrives an air of doubt about his ability to speak effectively. This rhetorical strategy called the dubitatio was recommended by the rhetorical handbooks to speakers who were confronted with an unreceptive audience as a way to lend an impression of truth to their words. ${ }^{20}$ In this case, the orator's feigned oratorical uncertainty underlines the central message of his apologia: I am blameless in regard to the grain crisis. After the dubitatio, there are the conventional call for an attentive hearing and the claim to be speaking on behalf of the

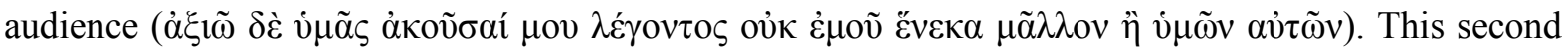
rhetorical commonplace is substantiated through a dilemmaton $(\varepsilon \dot{\imath} \mu \dot{\varepsilon} \nu \gamma \hat{\alpha} \rho \ldots$ \&i $\delta \dot{\varepsilon})$ : if the orator is innocent, the people would not want to hate one of their own citizens unjustly; while if he is not innocent, his speech would be harmful to him instead of helpful. ${ }^{21}$ Being proven a poneros in this way, Dio argues, would be worse than being stoned to death or consumed by fire. Either side of the dilemma thus leads to the conclusion that it is in the audience's best interest to grant the orator an attentive hearing. The second part of the dilemmaton, moreover, constitutes a meta-rhetorical statement that excludes the possibility of Dio deceiving his audience through his speech; another clever way to

\footnotetext{
${ }^{15}$ For public oratory as a way into the ideas and assumptions that were shared by a political community, see Ober 1989, 43-49.

${ }^{16}$ For the old view, see Jones 1940, 157-191, 270-276; de Ste. Croix 1981, 300-326, 518-537, 609-617; Quaß 1993; Pleket 1998.

${ }^{17}$ Ma 2000; Zuiderhoek 2008; Heller 2009; Fernoux 2011; Brélaz 2013; Oppeneer 2018.

${ }^{18}$ For some recent scepticism, see Wörrle 2004; 2005; Gleason 2006, 234; van der Vliet 2011, 156, 181-182; Schuler and Zimmerman 2012, 617-618; Schuler 2014, 254.

${ }^{19}$ On justice and injustice as deliberative topics, see Arist. Rh. 1.3.5, 1358b20-25; 1.6.9, 1362b12; Ps.-Arist. Rh.Al. 1.2.4, 1423a30-35; Hermog. Stat. 28.15-29.4.

${ }^{20}$ Lausberg 1998, §776. See e.g. Cic. Inv. 1.17.25; Rhet. Her. 1.6.10; Quint. Inst. 9.2.19.

${ }^{21}$ The second-century AD rhetorician Hermogenes of Tarsus described the dilemmaton as 'a figure of speech with a reputation for startling effect and truth' (Inv. 4.6; transl. Kennedy 2005, 169). Cf. also Hermog. Stat. 5.20-21; Arist. Rh. 2.23.15, 1399a17-28.
} 
downplay his rhetorical abilities and take away popular suspicion of clever speakers. ${ }^{22}$ The prooimion is concluded with the declaration that fire and stones constitute the strength of bandits and madmen

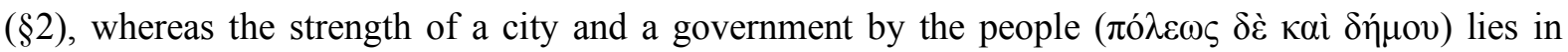

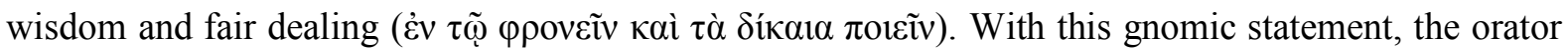
urges his audience to live up to the standards of popular government. The maxim not only brings home the message that problems should be resolved through public deliberation and not through violent action but also portrays the speaker as an authoritative and morally good man, character traits that are associated with the role of political adviser. ${ }^{23}$ The rhetorical devices employed in the prooimion (i.e. dubitatio, dilemmaton, meta-rhetorical and gnomic statements) thus aim to redefine the speakeraudience relation by portraying the orator as a truthful and unjustly persecuted man.

After this introduction, the way is open to discuss the issue at hand. The orator's biggest rhetorical challenge is his prior êthos, the image the audience has of him before stepping up to the speaker's platform, which is shaped by the stereotype of the bad rich man who fails to live up to, or even actively violates, widely shared views about what counted as proper elite behaviour in times of scarcity. If he is going to be persuasive, Dio has to rework and transform the people's perception of his character. To this end, he constructs a counter image that is in line with the demands of his rhetorical agenda.

\section{Family, Charis and Liturgies}

Being confronted by a hostile audience, Dio does well not to start off talking about himself. He first invokes the generosity and patriotism displayed by his family (\$2-4) as an indirect means of selfcharacterisation. According to the orator, his audience was well aware that his father was a good man

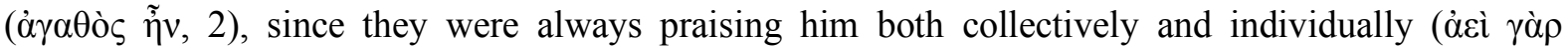

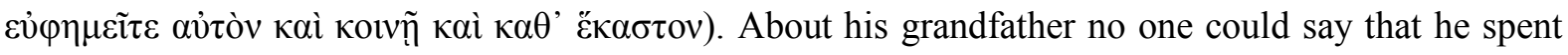

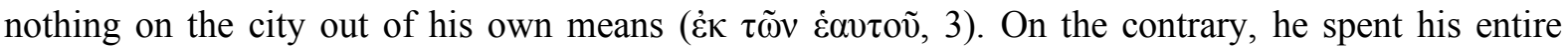

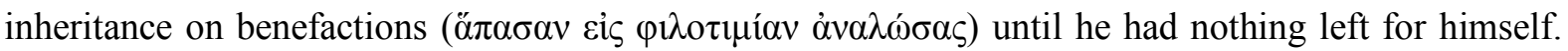
His grandfather similarly stood out for his generosity. Although he enjoyed the 'friendship and esteem'

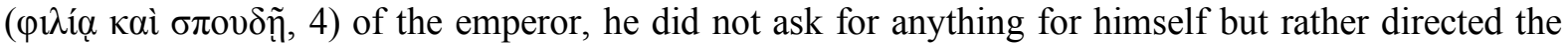
emperor's 'goodwill' ( $\pi \rho 0 \theta v \mu i \alpha v)$ towards his fatherland. ${ }^{24}$ Dio then explains to his audience why he

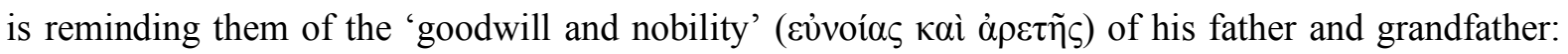

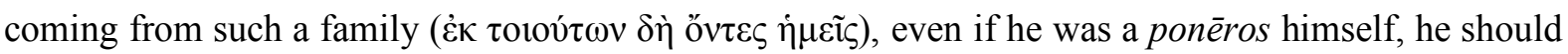

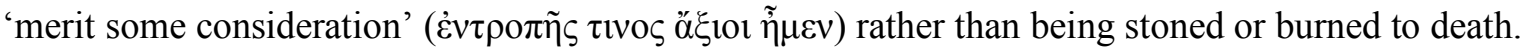

Dio's argument here almost reads like an inscription, as he highlights the ethical qualities of his father and grandfather without pointing out the specific benefits they conferred upon the community. Philotimia and eunoia pros ton demon are, of course, common motives in honorific inscriptions for civic benefactors. Even the statement that his grandfather spent all that he had on benefactions might well be more than a rhetorical flourish. From the letters of Pliny the Younger and Plutarch's essays, we know that financial ruin on account of excessive gift giving presented a real danger. ${ }^{25}$ The impoverished benefactor even became a topos in inscriptions, since it could be seen as the ultimate proof of a person's

\footnotetext{
${ }^{22}$ The dangers of rhetorical training for a political system based on public deliberation were widely recognized by critics of democracy and participating orators alike. Cf. Ober 1989, 165-177.

${ }^{23}$ Rhetorical handbooks regarded gnomic statements as a highly effective tool for moral self-advertisement. See e.g. Arist. Rh. 2.21.16, 1395b12-17; Nicol. Prog. 464.5-6 Sp. III; Quint. Inst. 8.5.32.

${ }^{24}$ Loeb transl.

${ }^{25}$ Plu. Praec. ger. reip. 822d-823d; De vit. aer. 830e; Plin. Ep. 10.110.2. Cf. also D.Chr. 66.3.
} 
willingness to place the interests of the community above that of his own. ${ }^{26}$ An honorific inscription from first-century BC Epidaurus, for example, specifies that a certain Aristobulus was generous to the degree of endangering his own livelihood $\left(I G \mathrm{IV}^{2} \mathrm{I} .65\right) .{ }^{27}$ Furthermore, the way in which Dio calls upon his audience to grant him the consideration he deserves on account of his ancestors resembles the ' $\dot{\varepsilon} \kappa$ $\pi \rho \gamma^{\prime} v \omega v$ formula' that is frequently found in contemporary honorific inscriptions. ${ }^{28}$ The Prusan inscription for the honour-loving agoranomos cited above, for example, relates the benefactions of the honorand's father before concluding that the honorand had been generous in the tradition of his

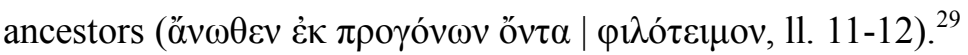

In the imperial period references to the achievements of ancestors become increasingly common in honorific epigraphy. A small group of wealthy families stressed their noble ancestry when they were honoured in order to present their claim to future offices and the corresponding dignity as natural. Historians have interpreted this development as a sign of the emergence of an exclusive class of leading citizens and the oligarchisation of the Greek city. ${ }^{30}$ In this view, the cities' willingness to recognize the qualities of leading citizens and their families signalled the widespread acceptance of aristocratic notions about civic virtue and the erosion of democratic values. ${ }^{31}$ It should be noted, however, that virtuous ancestry was not only a commonplace in imperial inscriptions. Social descent was one of the most important topoi for character construction in rhetorical handbooks throughout antiquity. ${ }^{32}$ Instead of explicitly attributing character traits to a person, this technique describes a person's character in an indirect way. It provides attributes, in this case membership of a specific family, from which the audience should infer certain characteristics. The topos of social descent featured prominently in the speeches of the Attic orators, especially those in which the character of the speaker was under attack. In a speech from the hand of Isaeus, for example, the speaker tells the jury that the character of the claimants can be judged by looking at the behaviour of their father who had proven himself a worthy citizen in performing his liturgies (4.27). In a speech by Lysias, the defendants make a play on the commonplace appeal to pity by presenting one's children to the jury. Instead of producing their weeping children, they list the benefits the people received due to their father's patriotism and their own (20.3435). Referring to one's family thus presented a well-known and legitimate way of establishing one's character in public oratory, even in a democratic context. It is no surprise, therefore, that Dio falls back on the characterising potential of his family at a time when his own reputation was under attack.

Besides the usefulness of family for character construction, Dio also refers to his father and grandfather for another reason. He recalls their goodwill and virtue to argue that even if he was a

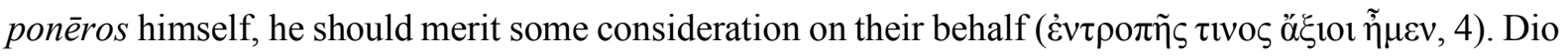
thus refers to his family's liturgies in order to cash in the favour the community owed his father and grandfather on account of their public services. The idea that the fulfilment of public services entitled one to the gratitude of the community found its most prominent expression in the vast mass of honorific inscriptions produced by the late-Hellenistic and imperial poleis. ${ }^{33}$ The hortative clauses of honorific

\footnotetext{
${ }^{26}$ On this motive, see Danker 1982, 417-427.

${ }^{27}$ For a discussion, see Zuiderhoek 2007, 202.

${ }^{28}$ Salmeri 2000, 64.

${ }^{29}$ I.Prusa ad Olymp. 21.

${ }^{30}$ See e.g. Quaß 1993, 40-56, 58-59; Scholz 2008; 2015, 92; Schuler 2014, 266.

${ }^{31}$ Wiemer 2013, 65.

${ }^{32}$ For an overview, see De Temmerman 2010.

${ }^{33}$ On the do-ut-des mechanism behind the exchange of gift for honours, see Zuiderhoek 2009, 113-154; Domingo Gygax 2016, 26-35.
} 


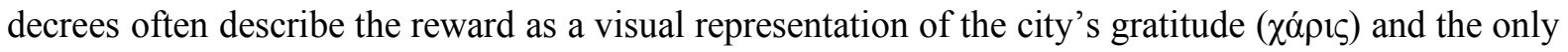
appropriate response to a benefactor's generosity. ${ }^{34}$

In classical Athens, orators and litigants were just as clear about the fact that expenditures for the common good rendered the community indebted to the benefactor. According to Aristotle, calmness could be instilled in a hostile audience by making them regard those with whom they were angry as

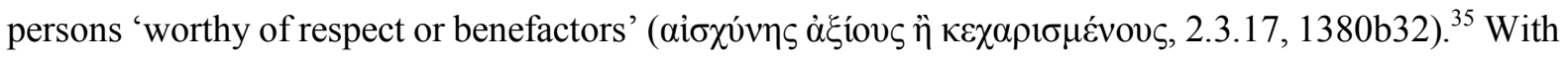
references to the liturgies performed in the past, a speaker more or less explicitly pointed out to his audience that they had incurred a debt that could be repaid in the present moment. ${ }^{36}$ In a speech written by Andocides, the speaker explicitly states that the services of his ancestors were not only motivated by their goodwill towards the people but also by the expectation that someday the people would return the favour if they or any of their children would be in danger or distress (1.141). In On the Crown, Demosthenes claims that taking away his honours would deprive him of the gratitude that was owed to him (18.112), while a client of Lysias tells his audience that his public services were motivated by the belief that he could one day request the people to return the favour (20.30-31). The similarities between Dio's rhetoric and that of the Attic orators suggest that references to virtuous parents or ancestors are not necessarily incompatible with democratic ideology. Just as the Athenian orators, Dio refers to his family in order to portray himself as standing in a tradition of men who fulfilled their services to the community. I would argue that what we see in the $46^{\text {th }}$ oration and, by extension, in inscriptions is not the erosion of democratic values or the aristocratic notion that virtue is based on descent. In an aristocratic society, the primary indicator of status is one's family rather than one's personal achievements. ${ }^{37}$ In honorific epigraphy, however, the virtue of both the honorand and his ancestors depended on their merits and value to the city. A person's social descent was never sufficient to claim virtue. Even descendants of the most illustrious ancestors had to supplement their family's virtue with that of their own.

Just as in honorific inscriptions, Dio not only reminds the people of his family's generosity, but also calls upon his audience to take into consideration his own actions. First, he claims that the inheritance his father left him was much smaller than it was reputed to be and less valuable than that of others (§5). ${ }^{38}$ The four hundred thousand drachmas his father was owed at the moment he passed away proved difficult to recover, since he had relied on his influence to recuperate these loans instead of securing them by bond. In spite of these difficulties, however, Dio did not avoid his liturgical duties. He even claims that he had performed the greatest liturgies and that no one in the city had more of them to his

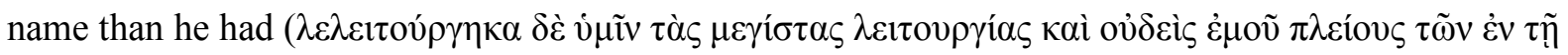
$\pi$ ó $\lambda \varepsilon 1,6)$. The orator further underlines his extraordinary generosity by stating that, as his audience

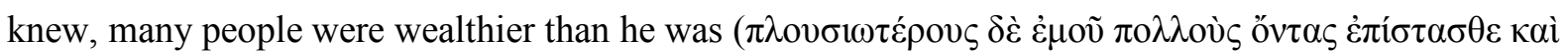

\footnotetext{
${ }^{34}$ See e.g. I.Sestos 19.1, 11. 86-89 (130-120 BC): 'so that one can see that the demos honours the noble among

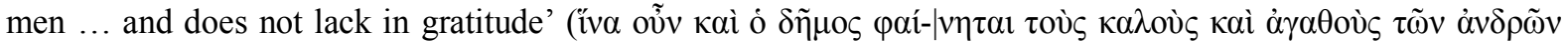

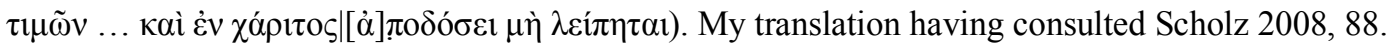

${ }^{35}$ Transl. Kennedy 2007.

${ }^{36}$ Ober 1989, 226-233. Although overt charis-obligations feature almost exclusively in forensic oratory, there are some attestations in deliberative oratory (i.e. And. 2; Th. 1.41.1). As an apologia, Dio's speech deals with his reputation and past actions, which explains the use of forensic techniques and strategies in what formally would qualify as a demegoric speech.

${ }^{37}$ Fisher and van Wees 2015, 19.

${ }^{38}$ An interesting parallel can be found in a speech from Lysias $(19.11,45-52)$ in which the defendant claims that it is something of a rule of life to find your inheritance to be much smaller than what everybody reports it to be.
} 
$\alpha \vdots$ toí). Dio thus begins the account of his own actions by downplaying the wealth he inherited from his father. This seems to be a deliberate strategy. As Marc Kleijwegt has shown, the portrayal of family achievements in inscriptions not only brought prestige to the honorand but also made him vulnerable to public pressure. ${ }^{39}$ Insisting on the past generosity of one's family when confronting a hostile audience in a period of crisis is a risky tactic for someone who was not keen on being elected as market supervisor. For this reason, Dio stresses not only that he has already performed the most and greatest liturgies, but also that there were many citizens that were wealthier than he was. Especially, the first part of this claim seems difficult to believe, since the oration is generally regarded as belonging to Dio's early career. Nevertheless, the liturgies mentioned by Dio must have been known to have happened in some sense. ${ }^{40}$ As Matthew Christ has argued for classical Athens, rich citizens were more or less free to exaggerate about the number of liturgies they performed and the way in which they were fulfilled (e.g. voluntarily rather than compelled). At the same time, however, they were careful not to make claims that could be easily contradicted. For this reason, they often avoided talking about specific instances and rather lumped their public services together. ${ }^{41}$ The same more or less applied for claims about poverty and wealth, which functioned as ideological and rhetorical constructs rather than reflections of reality. ${ }^{42}$ In the end, the veracity of Dio's double claim is irrecoverable. What is more interesting, I would argue, is the strategy that lies behind this claim.

The orator's emphasis on his liturgical track record is meant to appease his audience, evoke the people's gratitude and demand a favourable treatment in return. The following assertion of relative poverty is designed to maximise the return in goodwill from the liturgies he performed for the common good. At the same time, it shifts the focus of popular resentment away from the orator and towards those rich men who were supposedly less generous and patriotic than he was. The arguments supplied by Dio are reminiscent of the skepsis and antidosis procedures of classical Athens, which were in place in order to ensure that the burden of liturgies was divided equally among the city's wealthiest citizens. Inequities in the distribution of financial obligations were perceived of as unfair and inconsistent with democratic ideology, which dictated that each citizen should contribute to the community according to his abilities. ${ }^{43}$ While Dio has shown that he is likely to use his wealth in the common interest, these other, wealthier men are placed outside the community shared by the orator and his audience. In this way, he aims to drive a wedge between these men and the goodwill of the demos. It is clear that the people who were to be charged with the supervision of the market should be sought among this group.

In addition to soliciting the goodwill of the audience, past liturgies are also a highly effective tool for self-advertisement. The topic of personal achievements ( $\pi \rho \alpha \dot{\xi} \xi \varepsilon \varsigma$ ) was generally regarded as one of the strongest methods for character construction. ${ }^{44}$ Dio's recollection of the liturgies performed by himself serves as an argument from probability (દikós): the allegations going around must be false, the orator implies, since they are inconsistent both with the collective èthos of his family and his individual

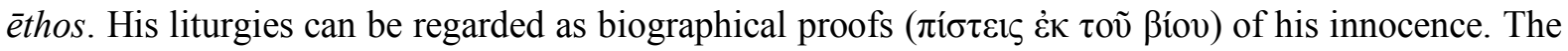

\footnotetext{
${ }^{39}$ Kleijwegt 1994, 65-67, referring to the case of the councillor Achilles of Hermapolis who was pressured to

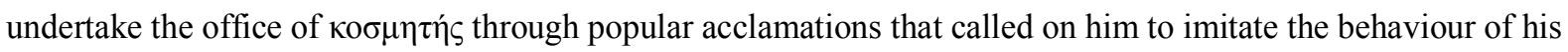
father (P.Ryl. 77, 1. 34).

${ }^{40}$ Cf. Bekker-Nielsen 2008, 140 n. 12.

${ }^{41}$ Christ 2006, 200-202.

${ }^{42}$ Cecchet 2016.

${ }^{43}$ See Christ 2006, 184-187.

${ }^{44}$ See Hermog. Stat. 46.16-17. The topic of personal achievements is one of the few topoi that occur in almost every author of epideictic and invention theories. See De Temmerman 2010, 33-34.
} 
same tactic occurs in Athenian forensic oratory. Public services were not only mentioned with an eye to obtaining the jury's charis, but also as evidence of good character that showed how unlikely it was that the defendant was guilty of the charges brought against him.

\section{Rhetorical Abilities}

After downplaying his wealth and stressing his rich liturgical record, Dio calls upon his audience to

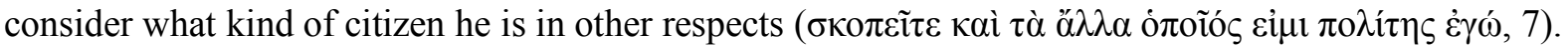
He begins by asserting that even though his land is spread out over the city's territory, none of his neighbours, many of whom were poor, has ever brought charges against him for being deprived of something or being evicted. Furthermore, even though he is neither over-clever as a speaker (oü $\tau \varepsilon$

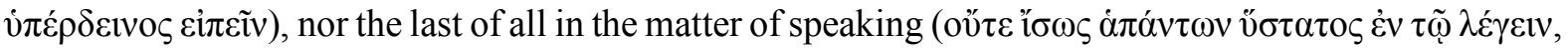
8), he has not used his persuasive powers at the expense of his fellow citizens. Through a series of rhetorical questions, Dio asks his audience whether he has ever harmed someone with his words ( $\dot{\varepsilon} v \tau \tilde{\varphi}$ $\lambda o ́ \gamma(\dot{\varepsilon} \lambda \hat{\delta} \pi \eta \sigma \alpha)$ or used his speaking abilities to defend or attack others in illegitimate lawsuits either

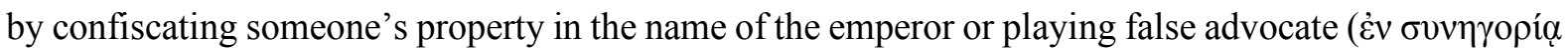
$\pi \rho \circ v \delta \omega \kappa \alpha)$. The use of rhetorical questions can be dangerous when confronted with a hostile audience, because their response cannot be controlled. Throughout his speech Dio nevertheless uses no less than ten rhetorical questions, seven of them occurring in the paragraphs dealing with the accusations aired against him (§6-9). The success of this tactic depends largely on the orator's delivery. A rapid succession of questions prevents hecklers or rival politicians from vocalising a response. The rhetorical questions give the impression of dialogue with the audience, while simultaneously steering them towards the desired response. The orator's frequent use of this tactic supports his aporetic stance, which suggests that there is indeed no reason for the people to be angry with him.

From this passage, it is clear that an orator's activities in the courts could result in a bad reputation. Dio forcefully argues that he was neither the subject of investigation himself nor used his rhetorical abilities to defend or attack others in court. In a later oration, he similarly points out that he avoided the courts, except for the one time when he took on the role of Demosthenes for someone who was being conned out of his inheritance by his guardians (43.6-7). Again, there are many parallels to be found in the Attic orators. Suspicion of clever speakers played an important role in the rhetoric and anti-rhetoric of democratic Athens. ${ }^{45}$ As Josiah Ober has pointed out, the topoi 'I am an inexperienced speaker' and its logical corollary 'My opponent is a skilled speaker' are among the most used commonplaces in classical oratory. ${ }^{46}$ The most powerful example of an over-clever speaker was the sycophant, someone who tried to enrich himself through malicious lawsuits. In a speech of Isocrates, the speaker defends his client against the charge of malicious prosecuting by pointing out that he was rich and unskilled in speaking, whereas everybody knows that sycophants tended to be poor and clever at speaking (Isoc. 21.5). The topos of the inexperienced speaker is almost exclusively found in judicial speeches that were written for private citizens who could sustain the fiction of their inexperience. Expert politicians, the rhêtores who frequently spoke in the assembly, on the other hand, did not make claims to poverty and rhetorical inability because their claim to political leadership rested on the possession of these elite characteristics. ${ }^{47}$ What politicians needed to show was their allegiance to the public good. The perception of being an over-clever and self-serving speaker should therefore be avoided at all costs.

\footnotetext{
${ }^{45}$ See e.g. Lys. 19.2; 17.1; 31.2; 31.4; D. 55.2; 55.7; Hyp. 1.19-20; 4.11; Aesch. 3.229.

${ }^{46}$ Ober 1989, 165-177; Cf. also Hesk 2000, 202-241.

${ }^{47}$ Ober 1989, 177-178.
} 
Like the Attic orators, Dio does not deny his rhetorical abilities (or his wealth). He does, however, insist that he is not over-clever or uses his abilities to profit at the cost of his fellow citizens. He thus presents himself as embodying the ideal of the vir bonus dicendi peritus, someone who combines his rhetorical abilities with moral integrity. ${ }^{48}$

\section{Common Knowledge}

Having established his character in this way, Dio finally addresses the issue at hand: his supposed involvement in the grain crisis $(\S 8)$. In this passage, he needs to refute, first of all, the allegation that he was stocked up with grain and, secondly, that he was unwilling to provide money for the purchase of grain despite being involved in the moneylending business. Contemporary stasis-theory would identify

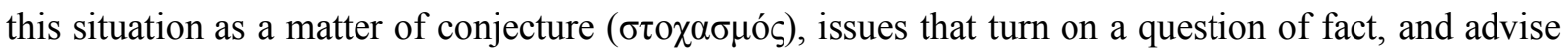

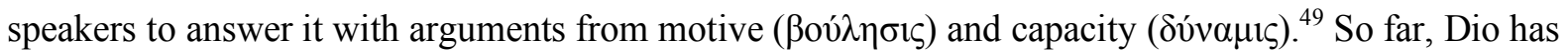
concentrated on arguments from motive exploiting some of the topics of person (i.e. social descent, actions, wealth and speech) in order to show that he was not the kind of person that engaged in uncivic behaviour. Now, he turns to an argument from capacity. According to the orator, his audience was well

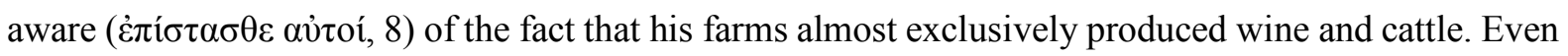
in unusually productive years his lands produced barely enough grain to meet the demands of his own household. With regard to his supposed unwillingness to provide money for the purchase of grain, he

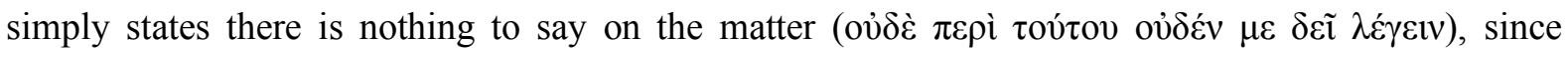

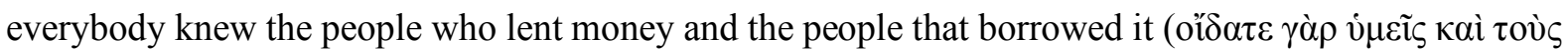

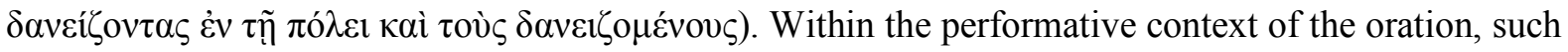
a statement could have been strenghtened by gestures that directed the audience's attention to certain individuals. It is clear at any rate that Dio again attempts to shift the focus of the people's anger away from himself and towards others. If you want someone to provide money for the purchase of grain, he is signalling to his audience, there they are!

The orator's defence on these points has been described as evasive and rather pitiful: he simply denies the accusations without providing substantial arguments beyond the assertion that everybody knew that he was speaking the truth. ${ }^{50}$ This is, however, a recurring strategy throughout the oration. The virtuous character of his father and grandfather were also presented as commonly known (ov̉ $\delta \dot{\varepsilon} v \dot{\varepsilon} \mu \grave{\varepsilon}$

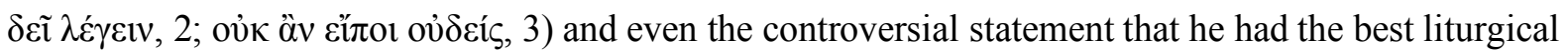

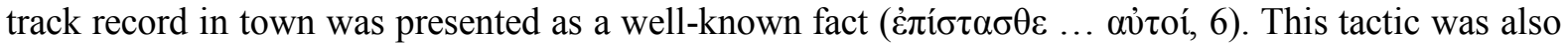
frequently used in classical oratory. ${ }^{51}$ A client of Lysias claims that he did not need to say anything about his character, since it was known to everyone (21.18-19). And a client of Isaeus states that he did not have to say anything regarding the bad character of his opponent because it was already well known (3.40). According to Aristotle, appeals to common knowledge were an effective tool to secure the acquiescence of those in the audience who did not know, because nobody wants to be seen as ignorant and everybody wants to share in the feelings of others ( $R h .3 .7 .7,1408 \mathrm{a} 32-36)$. The use of evidentials is a common rhetorical strategy, since they convey objectivity, reliability, and hence credibility, but within the context of the assembly this rhetorical move receives an additional dimension. According to Ober, the Attic orators frequently used the topos of 'everyone knows' because it gave their arguments a democratic authority. The underlying assumption of such statements was that the opinion of the

\footnotetext{
${ }^{48}$ For this famous dictum, see Cato Fil. 14; Sen. Con. 1.9.10; Quint. Inst. 12.1.1.

${ }^{49}$ Hermog. Stat. 46.9-47.6. According to stasis-theory, conjecture was the strongest line of defence.

${ }^{50}$ Cuvigny 1994, 126.

${ }^{51}$ See e.g. Aeschin. 1; D. 21.1, 16, 137, 149 and 167; Th. 6.11.4.
} 
community as a whole should be taken into consideration. The topos thus showed the speaker's adherence to, and solidarity with, egalitarian norms. ${ }^{52}$

Dio's use of the topos can be regarded as an attempt to include his audience in an assumption of shared knowledge. Evidently, the claims Dio made about his character, his lands and his moneylending were not undisputed. In this respect, it could be useful to approach his speech in the assembly as a 'rational ritual,' a communicative event that is aimed at creating common knowledge. Rational rituals often take place in inward-facing circles, such as theatres, since the intervisibility of audience members facilitates the development of information cascades. ${ }^{53}$ An information cascade occurs when a person creates or changes his own information by observing the behaviour of other people. ${ }^{54}$ A meeting of the ekklessia could thus function as a coordinating mechanism that generated common knowledge. It was the task of the assembly-goer to resolve uncertainty into certainty. To illustrate how this might have worked, we can imagine how Dio's claim about being on good terms with all of his poor neighbours would be received. Even though most audience members would have no information pertaining to this particular statement, they could make inferences about the knowledge of other audience members by observing their reactions and behaviour. In this way, they could indeed determine whether Dio was guilty or not on account of his words, just like the orator stated at the beginning of his speech (§1). In the end, it was through the people's vote that the orator's claims were evaluated and could eventually become common knowledge.

\section{A Final Proof from Character}

In a final attempt to explain the people's resentment towards him, Dio suggests that it had something

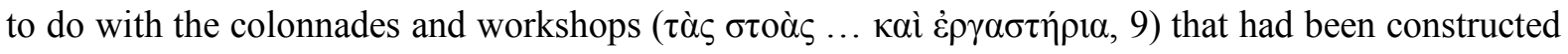
on a piece of land that he had purchased for fifty thousand drachmas. ${ }^{55}$ What the orator aimed to achieve by mentioning his construction activities is difficult to ascertain. It has been suggested that he might have been indicating that this recent transaction had drained his financial resources. ${ }^{56}$ Nevertheless, it would be hard to believe that someone who was capable of generating twice the amount of the official census requirement for councilmembers, a sum, moreover, that could have provided the entire population of Prusa with grain for a month, could not spare a few thousand drachmas for the provision of grain. ${ }^{57}$ What is more, as we saw earlier, Dio never claimed that he was poor. He only pointed out

\footnotetext{
52 Ober 1989, 148-151, 163. Cf. Hesk 2000, 227-231.

${ }^{53}$ Chwe 2001, 30-33, 74-93. For the application of these concepts to the ancient world, see Ober 2008, 190-210; Hedrick 2013, 390.

${ }^{54}$ Tomasello 2009, 71-72, speaks of recursive mind-reading: I know that you know that I know that you know, etc.

${ }^{55}$ When taken together with Dio's claim to have performed more liturgies than anybody else, this statement casts some doubt on the early date of the speech proposed by most scholars. The later stages of his local political career, were haunted by one or more building projects that also involved the construction of a colonnade $(40.9,47.17$, $48.11)$ and workshops $(40.9,45.9)$. In these later orations, there is no mention, however, that the land on which the building was constructed had been bought by Dio.

${ }^{56}$ Cuvigny 1994, 126-127.

57 The population size for Prusa is unknown but an estimate between 15 and 30 thousand seems reasonable, if we assume with Jones 1978, 5, that Prusa had about a third of the population of Pergamum. Whereas Jones estimates that Prusa had a population of about 50 thousand, recent estimates for the population of Asia Minor tend to be much lower. Given the recent estimations of Hanson 2011, who postulates a population between 50 and 90 thousand for Pergamum, it is more likely that Prusa had a population size between 15 and 30 thousand. With this estimate, the provision of grain at subsistence level for a month would cost 25 to 75 thousand denarii, assuming
} 
that he was not as rich as some believed him to be and that there were many men who were wealthier than him. It is more likely, therefore, that Dio is responding to voices among the Prusan population that blamed him for spending money on a self-serving real estate project instead of relieving the plight of the poor. He refutes this argument with a counterplea ( $\dot{\alpha} v \tau i \dot{\lambda} \eta \psi 1 \varsigma)$ : it is permissible and not forbidden to build on one's own land. ${ }^{58}$ When we look at the remark about the fifty thousand drachmas, it is important to note, moreover, that he claims to have paid a price that was much higher than its actual value. If we assume that Dio bought the land from the city, this statement can be regarded as a final character proof. The euergetic nature of the transaction once again shows his willingness to be generous with his money when it comes to his fellow-citizens.

\section{The Romans}

Before concluding his speech, Dio again stresses that he has spoken on behalf of the city rather than on his own behalf (§14). This time, he substantiates this claim with an argument from inexpedience ( $\tau$ ò $\beta \lambda \alpha \beta \varepsilon \rho o ́ v)$. According to Dio, he has spoken up out of fear that Prusa will be accused of being violent

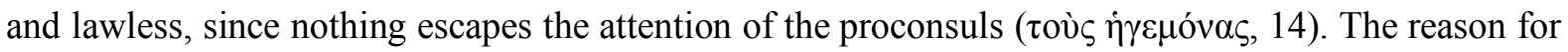
this is that the mistakes of the people ( $\tau \grave{\alpha} \tau \tilde{\omega} v \delta \eta \dot{\eta} \mu \omega v \dot{\alpha} \mu \alpha \rho \tau \eta \dot{\eta} \mu \alpha \tau \alpha$ ) are reported to them just as relatives report the behaviour of children who are too disorderly at home to their teachers. Several scholars have taken this simile as a thinly veiled threat to call in the Romans. ${ }^{59}$ It has been argued, moreover, that the analogy sets up a patriarchal dichotomy that confirms the alliance between the Greek civic elite (the relatives) and the Romans (the teachers) who work together to discipline the people (the unruly children) ${ }^{60}$ We should be careful, however, to suppose an easy collaboration between the local elite and the Roman authorities on account of this rhetorically invested passage. ${ }^{61}$ Threats of Roman intervention were ultimately of limited use because the local elite too had much to lose from such interference. ${ }^{62}$ In his advice for the aspiring politician, Plutarch, for example, criticises those who involve the Romans in local affairs, because this undermined the political functioning of the entire polis: council, assembly, courts and magistrates all lose their authority (Praec. ger. reip. 815a). ${ }^{63}$ What is more, Dio's own speech indicates that there was little cohesion among the Prusan elite. ${ }^{64}$ At several points in the oration, the orator points his finger towards those among his peers who were supposedly less patriotic than he was. Furthermore, the interjection in his reference to the proconsuls - 'I mean the

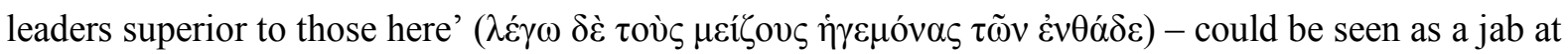
certain local officials, which suggests that the orator is distancing himself from any relatives that would report the misdeeds of the people. Regardless of the identity of these relatives, the conclusion Dio draws

a subsistence level of $250 \mathrm{~kg}$ wheat-equivalent per person per year and a price of 0.75 denarius per modius (= $6.55 \mathrm{~kg}$ ). For this method, see Hopkins 1980, 118-119.

${ }^{58}$ On counterplea, see Hermog. Stat. 48.4-9. The rhetorical handbooks would advise any opponents in the assembly to use objection by counter-representation: it is permissible to build on one's own land but not in this way or under these conditions (cf. Hermog. Stat. 48.10-49.8).

${ }^{59}$ Cuvigny 1994, 134; Fuhrmann 2014, 164-165.

${ }^{60}$ Perkins 2009, 83-84.

${ }^{61}$ Cf. Kokkinia 2006, 186.

${ }^{62}$ Zuiderhoek 2008, 441.

${ }^{63}$ On Dio's own policy of avoiding Roman intervention, see Salmeri 2000, 64.

${ }^{64}$ From Dio's later orations it is clear that political infighting among the elite was a recurring problem in Prusan politics. From the $43^{\text {rd }}$ oration, we know of a crisis that led to the exile and suicide of several influential citizens. The orator's building project was continuously opposed by his political rivals (Orr. 40, 45, 47, 48). 


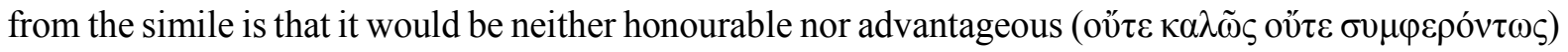
for the people of Prusa to continue their riotous behaviour. For this reason, he introduces the proposal for the election of supervisors for the market. This, he concludes, would be the decision of sensible people ( $\sigma \omega \varphi \rho \circ v o ̛ ́ v \tau \omega v \tau \varepsilon \dot{\alpha} v \theta \rho \omega ́ \pi \omega v \dot{\varepsilon} \sigma \tau i ́)$.

\section{Conclusion}

The $46^{\text {th }}$ oration is a polemic text in which Dio seeks to correct the people's negative perception of his persona and convince them to elect one of his peers as market supervisor. Over the last pages, I have tried to shed some light on the rhetorical strategies the orator employs to achieve this task. Whereas modern scholarship has described the oration's arguments either as evasive and mediocre or as the tactics of a manipulative and sometimes hypocritical bully, this article has tried to show that from an ideological point of view, the orator's rhetorical strategies were, in fact, very appropriate. ${ }^{65}$ His apologia constantly draws upon widely shared assumptions about the good polis and the good citizen. The oration is pervaded with self-referential passages and topoi that underscore the orator's adherence to communal values and ideals (e.g. 'I have performed the greatest liturgies,' 'I am not an over-clever speaker'). From an anachronistic, modern point of view, this focus on character could be seen as evasive and beside the question. Yet, ancient rhetoricians included the portrayal of the speaker's character among the proper grounds for conviction $(\pi i \sigma \tau \varepsilon 1 \zeta)$, proofs that provided the listener with good reasons to believe that something was or was not the case. ${ }^{66}$ According to Aristotle, this kind of ethical proof was particularly important for deliberative oratory. ${ }^{67}$ In the $46{ }^{\text {th }}$ oration, Dio systematically provides his audience with proofs that he was a good and virtuous citizen, someone who consistently put the community's interests above his own. Throughout the speech, he takes care to show that his elite attributes did not alienate him from his audience, on the contrary, they were actively employed in their interest. Despite his wealth, speaking ability and superior social position, his interests were identical to those of the community.

Together with Dio's other assembly speeches, the $46^{\text {th }}$ oration testifies to the existence of a vital tradition of popular political participation. From Dio's orations, it appears that the Prusan demos had to decide on controversial topics, from friendship treatises (Or. 40), civic honours (Orr. 44, 51) and building projects (Orr. 40, 45, 47 and 48) to the election of supernumerary council members (Or. 45) and various officials (Orr. 46, 48). What stands out from these later speeches, is the frequent and vehement opposition the orator encountered from his political rivals. Dio's fascinating account of assembly politics in the Euboicus (Or. 7), moreover, vividly describes the competitive clash between rival orators and the high degree of vocal participation from the audience that acclaimed, applauded, interrupted and laughed down the speakers that addressed them. ${ }^{68}$ This suggests that assembly-goers had to make up their minds by listening to politicians who set out competing ideas and conflicting views on what was best for the polis and its citizens.

The rhetorical strategies we encounter in the $46^{\text {th }}$ oration provide an important key to understanding the political ideology of imperial Prusa and the way in which local power relations were negotiated and legitimised. From the speech, it appears that the Prusan assembly functioned as the forum for a process of negotiation between elites with political aspirations and a dēmos that sought to direct those ambitions

\footnotetext{
${ }^{65}$ See Cuvigny 1994, 125-127, and Fuhrmann 2014, 162. Cf. also Veyne 1976, 313.

${ }^{66}$ For the concept of pisteis as 'proper grounds for conviction,' see Arist. Rh. 1.2.2-4, 1355b35-1356a13; 2.1.1-7, 1377b16-1378a20. For a discussion, see Dow 2015, 50-52, 88-89.

${ }^{67}$ Arist. Rh. 2.1.2-4, 1377b19-1378a6. The importance of ethical proofs for deliberative oratory is confirmed by several contributions in the volume by Derron 2016.

${ }^{68}$ On the Euboicus as evidence on contemporary assembly politics, see Ma 2000; Oppeneer 2018, 232-237.
} 
towards the benefit of the community. It is in this rhetorical dialogue that civic norms - rules for appropriate social and political behaviour - were established and monitored for compliance. These norms are best known to us from the epigraphic record. Yet, in contrast with inscriptions that present us with an idealised image of the relation between elites and their communities, the $46^{\text {th }}$ oration points to the existence of negotiation, debate and friction. As we have seen, the orator repeatedly appealed to the beliefs of his popular audience in a way that resembles the rhetoric of the Attic orators. Perhaps, it would go too far to argue that the ideology behind Dio's rhetoric was democratic. Imperial notions of civic society were decidedly more hierarchical and les egalitarian than those of classical Athens. Nevertheless, I would argue that Dio's rhetoric sustained and reproduced an ideology that was decidedly civic in nature and that monitored and kept in check elite power, wealth and education. The exceptionality of Dio's orations as the only extant corpus of post-Classical assembly speeches raises the question of whether or not they can be taken as representative for assembly politics and demegoric rhetoric in the Greek city under Rome. Although Dio was not an ordinary politician, the civic values in which his rhetoric was grounded were certainly not unique to Prusa. This much is clear from the thousands of inscriptions generated by the imperial Greek city. What Dio's assembly speeches show is the political struggle over the meaning of civic virtues and whether they applied to certain persons or not.

Unfortunately, we can only speculate about the effectiveness of Dio's rhetoric and the felicity of his speech acts. Did the people charge some of his peers with the supervision of the market, or did they call on him to undertake the liturgy unconvinced by his confident speech? What we can say with certainty, however, is that it was the assembly that decided. This is particularly clear at the end of Dio's proposal where he states that if it would prove impossible to find wealthy men who had not performed any

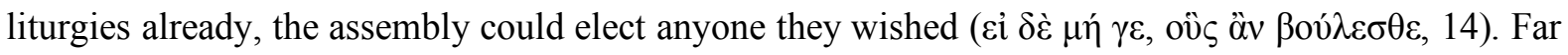
from being an outdated or irrelevant institution, the assembly of Prusa continued to provide the people with the opportunity to assert real influence in local politics.

\section{Bibliography}

Alston, R., and van Nijf, O.M., eds. (2008). Feeding the Ancient Greek City. Leuven.

Bekker-Nielsen, T. (2008). The Urban Life and local Politics in Roman Bithynia. The Small World of Dion Chrysostomos. Aarhus.

Brélaz, C. (2013). La vie démocratique dans les cités grecques à l'époque impériale. Topoi (Lyon) 18.2, pp. 367-399.

Broekaert, W.L.W., and Zuiderhoek, A. (2012). Food and Politics. In: P. Erdkamp, ed., A Cultural History of Food, Oxford, pp. 75-94.

Brunt, P.A. (1994). The Bubble of the Second Sophistic. BICS 39.1, pp. 25-52.

Capdetrey, L., and Hasenohr, C. (2012). Surveiller, organiser, financer. Fonctionnement de l'agoranomia et statut des agoranomes dans le monde égéen. In: L. Capdetrey and C. Hasenohr, eds., Agoranomes et édiles. Institutions des marchés antiques, Bordeaux, pp. 13-34.

Cecchet, L. (2016). Poverty in Athenian Public Discourse. From the Eve of the Peloponnesian War to the Rise of Macedonia. Stuttgart.

Christ, M.R. (2006). The Bad Citizen in Classical Athens. Cambridge.

Chwe, M.S.Y. (2001). Rational Ritual. Culture, Coordination and Common Knowledge. Princeton.

Corsten, T. (1991). Die Inschriften von Prusa ad Olympum. Bd. 1. Bonn.

---. (1993). Die Inschriften von Prusa ad Olympum. Bd. 2. Bonn.

Cuvigny, M., ed. (1994). Dion de Pruse. Discours Bithyniens (Discours 38-51). Paris. 
Danker, F.W. (1982). Benefactor. Epigraphic Study of a Graeco-Roman and New Testament Semantic Field. St. Louis (Mo.).

de Ste. Croix, G.E.M. (1981). The Class Struggle in the Ancient Greek World. From the Archaic Age to the Arab Conquests. Ithaca.

De Temmerman, K. (2010). Ancient Rhetoric as a Hermeneutical Tool for the Analysis of Characterization in Narrative Literature. Rhetorica 28.1, pp. 23-51.

Derron, P. ed., (2016). La rhétorique du pouvoir. Une exploration de l'art oratoire délibératif grec. Genève.

Domingo Gygax, M. (2016). Benefaction and Rewards in the Ancient Greek City. The Origins of Euergetism. Cambridge.

Dow, J. (2015). Passions and Persuasion in Aristotle's Rhetoric. Oxford.

Erdkamp, P. (2002). A Starving Mob has no Respect. Urban Markets and Food Riots in the Roman World, 100 B.C.-400 A.D. In: L. de Blois and J. Rich, eds., The Transformation of Economic Life under the Roman Empire, Amsterdam, pp. 93-115.

---. (2008). Grain Funds and Market Intervention in the Roman World. In: R. Alston and O.M. van Nijf, eds., pp. 109-125.

Fernoux, H.-L. (2011). Le Demos et la Cité. Communautés et assemblées populaires en Asie Mineure à l'époque impériale. Rennes.

Fisher, N., and van Wees, H. (2015). The Trouble with 'Aristocracy.' In: N. Fisher and H. van Wees, eds., Aristocracy in Antiquity. Redefining Greek and Roman Elites, Swansea, pp. 1-58.

Fuhrmann, C.J. (2014). Dio Chrysostom as a Local Politician. A Critical Reappraisal. In: L. Brice and D. Slootjes, eds., Aspects of Ancient Institutions and Geography, Leiden, pp. 161-176.

Garnsey, P. (1988). Famine and Food Supply in the Graeco-Roman World. Responses to Risk and Crisis. Cambridge.

Gleason, M.W. (2006). Greek Cities under Roman Rule. In: D.S. Potter, ed., A Companion to the Roman Empire, Malden (Mass.), pp. 228-249.

Gray, B.D. (2015). Stasis and Stability. Exile, the Polis, and Political Thought, c. 404-146 BC. Oxford. Hanson, J.W. (2011). The Urban System of Roman Asia Minor and Wider Urban Connectivity. In: A. Bowman and A. Wilson, eds., Settlement, Urbanization, and Population, Oxford, pp. 229-275.

Hedrick, C.W. (2013). Spaces of Government. In: H. Beck, ed., A Companion to Ancient Greek Government, Oxford, pp. 383-399.

Heller, A. (2009). La cité grecque d'époque impériale. Vers une société d'ordres ? Annales (HSS) 64.2, pp. 341-373.

Hesk, J. (2000). Deception and Democracy in Classical Athens. Cambridge.

Hopkins, K. (1980). Taxes and Trade in the Roman Empire (200 B.C.-A.D. 400). In: JRS 70, pp. 101125.

Jones, A.H.M. (1940). The Greek City from Alexander to Justinian. Oxford.

Jones, C.P. (1978). The Roman World of Dio Chrysostom. Cambridge.

Kemezis, A.M. (2019). Beyond City Limits. Citizenship and Authorship in Imperial Greek Literature. In: K. Berthelot and J. Price, eds., In the Crucible of Empire. The Impact of Roman Citizenship upon Greeks, Jews and Christians, Leuven, pp. 73-103.

Kennedy, G.A., ed. (2005). Invention and Method. Two Rhetorical Treatises from the Hermogenic Corpus. Atlanta.

---., ed. (2007). Aristotle. On Rhetoric. A Theory of Civic Discourse. Oxford.

Kleijwegt, M. (1994). Voluntarily, but under pressure. Voluntarity and Constraint in Greek Municipal Politics. In: Mnemosyne: A Journal of Classical Studies 47.1, pp. 64-68. 
Kokkinia, C. (2006). The Governor's Boot and the City's Politicians. Greek Communities and Rome's Representatives under the Empire. In: A. Kolb, ed., Herrschaftsstrukturen und Herrschaftspraxis. Konzepte, Prinzipien und Strategien der Administration im römischen Kaiserreich, Berlin, pp. 181-189.

Lausberg, H. (1998). Handbook of Literary Rhetoric. A Foundation for Literary Study. Leiden.

Ma, J. (2000). Public Speech and Community in the Euboicus. In: S. Swain, ed., Dio Chrysostom. Politics, Letters, and Philosophy. Oxford, pp. 108-124.

Migeotte, L. (2015). Les pouvoirs des agoranomes dans les cités grecques. In: L. Migeotte, ed., Économie et finances publiques des cités grecques, Lyon, pp. 27-40.

Ober, J. (1989). Mass and Elite in Democratic Athens. Rhetoric, Ideology, and the Power of the People. Princeton.

---. (2008). Democracy and Knowledge. Innovation and Learning in Classical Athens. Princeton.

Oppeneer, T. (2018). Assembly Politics and the Rhetoric of Honour in Chariton, Dio of Prusa and John Chrysostom. Historia. Zeitschrift für Alte Geschichte 67.2, pp. 223-243.

Perkins, J. (2009). Roman Imperial Identities in the Early Christian Era. New York.

Pleket, H.W. (1998). Political Culture and Political Practice in the Cities of Asia Minor in the Roman Empire. In: W. Schuller, ed., Politische Theorie und Praxis im Altertum, Darmstadt, pp. 204217.

Quaß, F. (1993). Die Honoratiorenschicht in den Städten des griechischen Ostens. Untersuchungen zur politischen und sozialen Entwicklung in hellenistischer und römischer Zeit. Stuttgart.

Salmeri, G. (2000). Dio, Rome, and the Civic Life of Asia Minor. In: S. Swain, ed., Dio Chrysostom. Politics, Letters, and Philosophy, Oxford, pp. 53-92.

Scholz, P. (2008). Die 'Macht der Wenigen' in den hellenistischen Städten. In: H. Beck, P. Scholz, and U. Walter, eds., Die Macht der Wenigen. Aristokratische Herrschaftspraxis, Kommunikation und 'edler' Lebensstil in Antike und Früher Neuzeit, München, pp. 71-99.

---. (2015). Städtische Honoratiorenherrschaft und Gymnasiarchie in der Kaiserzeit. In: P. Scholz and D. Wiegandt, eds., Das kaiserzeitliche Gymnasion. Wissenskultur und gesellschaftlicher Wandel, Berlin, pp. 79-96.

Schuler, C. (2014). Local Elites in the Greek East. In: C. Bruun and J. Edmondson, eds., The Oxford Handbook of Roman Epigraphy, Oxford, pp. 250-273.

Schuler, C., and Zimmerman, K. (2012). Neue Inschriften aus Patara I. Zur Elite der Stadt in Hellenismus und früher Kaiserzeit. Chiron 42, pp. 567-626.

Strubbe, J.H.M. (1987). The Sitonia in the Cities of Asia Minor under the Principate (I). EA 10, pp. 4582.

---. (1989). The Sitonia in the Cities of Asia Minor under the Principate (II). EA 13, pp. 99-122.

Thompson, E.P. (1971). The Moral Economy of the English Crowd in the Eighteenth Century. $P \& P$ 50.1, pp. 76-136.

Tilly, L.A. (1971). The Food Riot as a Form of Political Conflict in France. The Journal of Interdisciplinary History 2.1, pp. 23-57.

Tomasello, M. (2009). Why We Cooperate. Cambridge (Mass.).

van der Vliet, E.C.L. (2011). Pride and Participation. Political Practice, Euergetism, and Oligarchisation in the Hellenistic Polis. In: O.M. van Nijf and R. Alston, eds., Political Culture in the Greek City after the Classical Age, Leuven, pp. 55-184.

van Nijf, O.M., and Alston, R., eds. (2011). Political Culture in the Greek City after the Classical Age. Leuven. 
van Nijf, O.M. (2013). Affective Politics. The Emotional Regime in the Imperial Greek City. In: A. Chaniotis and P. Ducrey, eds., Unveiling Emotions II. Emotions in Greece and Rome. Texts, Images, Material Culture, Stuttgart, pp. 351-368.

Veyne, P. (1976). Le pain et le cirque. Sociologie historique d'un pluralisme politique. Paris. von Arnim, H. (1899). Zum Leben Dios von Prusa. Hermes 34.3, pp. 363-379.

Vujčić, N. (2009). Greek Popular Assemblies in the Imperial Period and the Discourses of Dio of Prusa. EA 42, pp. 157-169.

Wiemer, H.-U. (2013). Hellenistic Cities. The End of Greek Democracy? In: H. Beck, ed., A Companion to Ancient Greek Government, Oxford, pp. 54-69.

Wörrle, M. (2004). Maroneia im Umbruch. Von der hellenistischen zur kaiserzeitlichen Polis. Chiron 34, pp. 149-167.

---. (2005). La politique des évergètes et la non-participation des citoyens. Le cas de Maronée sous l'Empereur Claude. In: P. Fröhlich and C. Müller, eds., Citoyenneté et participation à la basse époque hellénistique, Genève, pp. 145-161.

Zuiderhoek, A. (2007). The Ambiguity of Munificence. Historia: Zeitschrift für Alte Geschichte 56.2, pp. 196-213.

---. (2008). On the Political Sociology of the Imperial Greek City. GRBS 48.4, pp. 417-445.

---. (2009). The Politics of Munificence in the Roman Empire. Citizens, Elites, and Benefactors in Asia Minor. Cambridge.

---. (2013). No Free Lunches. Paraprasis in the Greek Cities of the Roman East. HSPh 107, pp. 1-29. 